\title{
DNA damage in mouse organs and in human sperm cells by bisphenol A
}

\author{
Sharma, Anoop Kumar; Boberg, Julie; Dybdahl, Marianne
}

Published in:

Toxicological and Environmental Chemistry

Link to article, DOI:

$10.1080 / 02772248.2018 .1529236$

Publication date:

2018

Document Version

Peer reviewed version

Link back to DTU Orbit

Citation (APA):

Sharma, A. K., Boberg, J., \& Dybdahl, M. (2018). DNA damage in mouse organs and in human sperm cells by bisphenol A. Toxicological and Environmental Chemistry, 100(4), 465-478.

https://doi.org/10.1080/02772248.2018.1529236

\section{General rights}

Copyright and moral rights for the publications made accessible in the public portal are retained by the authors and/or other copyright owners and it is a condition of accessing publications that users recognise and abide by the legal requirements associated with these rights.

- Users may download and print one copy of any publication from the public portal for the purpose of private study or research.

- You may not further distribute the material or use it for any profit-making activity or commercial gain

- You may freely distribute the URL identifying the publication in the public portal

If you believe that this document breaches copyright please contact us providing details, and we will remove access to the work immediately and investigate your claim 


\section{DNA damage in mouse organs and in human sperm cells by bisphenol A}

\section{Anoop Kumar Sharma, Julie Boberg \& Marianne Dybdahl}

To cite this article: Anoop Kumar Sharma, Julie Boberg \& Marianne Dybdahl (2018): DNA damage in mouse organs and in human sperm cells by bisphenol A, Toxicological \& Environmental Chemistry, DOI: 10.1080/02772248.2018.1529236

To link to this article: https://doi.org/10.1080/02772248.2018.1529236

Accepted author version posted online: 28 Sep 2018.

Submit your article to this journal $₫$

Џ Article views: 2

View Crossmark data ¿ 


\title{
DNA damage in mouse organs and in human sperm cells by bisphenol A
}

\author{
Anoop Kumar Sharma ${ }^{a}$, Julie Boberg ${ }^{b}$, Marianne Dybdahl ${ }^{\mathrm{c}}$ \\ a Technical University of Denmark, National Food Institute, Division of Risk Assessment \\ and Nutrition. Kemitorvet Building 201, 2800 Lyngby, Denmark. Tel.: +45 35887605. \\ E-mail: aksha@food.dtu.dk \\ b Technical University of Denmark, National Food Institute, Division of Diet, Disease \\ Prevention and Toxicology. Kemitorvet, Building 202, 2800 Lyngby, Denmark. Tel.: +45 \\ 93518911. E-mail: jubo@food.dtu.dk \\ c Technical University of Denmark, National Food Institute, Division of Diet, Disease \\ Prevention and Toxicology. Kemitorvet, Building 202, 2800 Lyngby, Denmark. Tel.: +45 \\ 93518946. E-mail: mdyb@food.dtu.dk. Present address: Saxocon, Diplomvej 372, 2800 \\ Lyngby, Denmark. Tel.: +45 93518946. E-mail: mdy@saxocon.com
}

Word Count: 4581

\begin{abstract}
:
The in vivo genotoxic potential of bisphenol A using the comet assay in mice and in human sperm cells in vitro without metabolizing enzymes was studied. Male mice were exposed by oral gavage to the following doses of bisphenol $\mathrm{A}(0,125,250$ and $500 \mathrm{mg} / \mathrm{kg}$ body weight). DNA damage was investigated in liver, kidney, testes, urinary bladder, colon and lungs cells. In testicular cells, a significant increase in DNA strand breaks was observed in the lowest, but not in the medium or highest dose groups. Histopathological investigation of the testicular samples did not show any treatment dose-related effects. No DNA strand breaks were observed in any of the other investigated tissues. In human sperm cells in vitro, bisphenol A did not induce DNA strand breaks.
\end{abstract}


Keywords: BPA, DNA damage, comet assay, mice, testes, human sperm cells

\section{Introduction}

Bisphenol A (BPA) is used as monomer in the manufacture of polycarbonates and epoxy resins for food contact materials such as beverage bottles, infant feeding bottles, and tableware.

BPA acts as an endocrine disrupter with oestrogenic properties (Kanno et al. 2001) and reproductive toxicity of BPA has been extensively investigated, showing toxicity in one and two generation reproductive studies (Christiansen et al. 2014; Tyl et al. 2008; Ema et al. 2001).

Studies on genotoxicity of BPA in vivo and in vitro have shown conflicting results. Recently, the European Food Safety Authority (EFSA) CEF Panel (Food Contact Materials, Enzymes, Flavourings and Processing Aids) assigned a likelihood level of "unlikely" to BPA genotoxicity (EFSA 2015). A temporary tolerable daily intake was set by EFSA in 2015 based on the endpoint "general toxicity" (EFSA 2015). However, EFSA has a plan ready for a new assessment of BPA in 2018.

Oral gavage as the exposure route has mostly been used in in vivo genotoxicity studies followed by drinking water exposure and intraperitoneal injection. Effects have been reported such as DNA strand breaks in lymphocytes, testicular cells, sperm cells, lungs, spleen and kidney, micronuclei formation and chromosome aberrations in bone marrow cells and polychromatic reticulocytes in peripheral blood, dominant lethal mutations, $\gamma \mathrm{H} 2 \mathrm{AX}$ foci formation in sperm cells, DNA adducts in liver and mammary tissue, aneuploidy in oocytes and achromatic lesion and c-mitotic effects in bone marrow cells (Ulutas et al. 2011; Tiwari et 
al. 2012; Tiwari and Vanage 2013; Wu et al. 2013; Atkinson and Roy 1995; Hunt et al. 2003; Naik and Vijaylakshmi 2009; Izzotti et al. 2009; Dobrzynska and Radzikowska 2013; Gajowik, Radzikowska and Dobrzynska 2013). On the other hand, several studies have reported negative findings following oral gavage and exposure via drinking water by investigating micronuclei formation and DNA strand breaks in bone marrow cells, lymphocytes, liver, kidney and spleen, as well as micronuclei formation and chromosome aberrations in bone marrow cells and hyperploidy and polyploidy in oocytes and sperm cells (Masuda et al. 2005; De Flora et al. 2011; Naik and Vijaylakshmi 2009; Gajowik, Radzikowska and Dobrzynska 2013; Pacchierotti et al. 2008). In most of the studies, DNA damage was investigated using the comet assay which is a sensitive method to detect DNA damage and even relatively small increases in DNA strand breaks could be of biological importance.

The aim of this study was to investigate the induction of DNA damage by BPA using the comet assay in male mice tissues after oral gavage exposure according to the OECD guideline (OECD 2014). The maximum tolerated dose was determined in a dose range finding study and used as the highest dose in the study. Therefore, applying human relevant doses of BPA were not an aim of this animal study. Several male mouse tissues were examined including the whole testes. Studies of DNA damage using the comet assay in human sperm cells after BPA exposure have been lacking. Therefore we additionally tested BPA in human sperm cells which are considered a sensitive in vitro model for the detection of DNA damage (Baumgartner et al. 2012). 


\section{Material and methods}

\section{Experimental design}

The animal study was conducted under conditions approved by The Danish Agency for Protection of Experimental Animals and the in-house Animal Welfare Committee. CD-1 male mice, 4 weeks of age and weighing about $30 \mathrm{~g}$, were purchased from Taconic MB (Lille Skensved, Denmark). Animals were allowed to acclimatize for a week. The mice were randomly divided into three dose groups and were housed individually in cages (Macrolon type III high, Techniplast Gazzada, Buguggiate, Italy) with wood bedding (Tapvei, Paekna, Estonia) under controlled conditions (temperature $22 \pm 1{ }^{\circ} \mathrm{C}$, relative humidity $55 \pm 5 \%, 12 \mathrm{~h}$ light/dark cycle, air change 10 times/h). The mice had free access to feed (Altromin 1324, Lage, Germany) and tap water acidified to $\mathrm{pH} 3.5$ with citric acid. During the acclimatization and study periods the mice were observed twice daily for any abnormalities in behaviour.

A dose range finding study was performed. Three mice were exposed twice at 8 o'clock a.m., $24 \mathrm{~h}$ apart by oral gavage to $500 \mathrm{mg} / \mathrm{kg}$ body weight (bw) of BPA (Sigma-Aldrich, Schnelldorf, Gemany, purity $>99 \%$, CAS no. 80-05-7). Corn oil (Sigma-Aldrich, CAS no. 8001-30-7) was used as the vehicle. The mice were dosed by oral gavage, $10 \mathrm{~mL} / \mathrm{kg}$ bw of suspensions of about $0.3 \mathrm{~mL}$ BPA in corn oil freshly prepared by ultrasonication (Janke \& Kunkel Ultraturrax T25, IKA-Labortechnik, Staufen, Germany) for ten minutes. The treatment resulted in changed behavior of the mice, they were less active (after both treatments and less activity was observed until $24 \mathrm{~h}$ after the second treatment) than three control mice that only received corn oil.

For the main study, five mice in five groups were fasted overnight. The next morning, three groups of animals received by gavage $10 \mathrm{~mL} / \mathrm{kg}$ bw of suspensions of $12.5,25$ and $50 \mathrm{mg} / \mathrm{mL}$ BPA in about $0.3 \mathrm{~mL}$ corn oil freshly prepared by ultrasonication (Janke \& Kunkel Ultraturrax T25, IKA-Labortechnik) for ten minutes, resulting in doses of 125, 250, and 500 
$\mathrm{mg} / \mathrm{kg}$ bw. The animals were given access to food and $24 \mathrm{~h}$ later, they received the same dose again. A positive control group of five mice received once by oral gavage $10 \mathrm{~mL} / \mathrm{kg}$ bw of an aqueous solution of $30 \mathrm{mg} / \mathrm{mL}$ ethyl methanesulfonate (EMS), (Sigma-Aldrich, CAS no. 6250-0) resulting in a dose of $300 \mathrm{mg} / \mathrm{kg} \mathrm{bw}$. A negative control group of five mice received 10 $\mathrm{mL} / \mathrm{kg}$ bw corn oil twice $24 \mathrm{~h}$ apart and treated the similar way as the dosed group animals.

Three hours after the second dosing the animals were anaesthetized in $\mathrm{CO}_{2} / \mathrm{O}_{2}$ and decapitated. After macroscopic examination, liver, kidney, testes, urinary bladder, colon and lungs were excised and weighed. Liver, kidney and lungs were cut into two to four pieces, each placed into separate cryotubes. The urinary bladder was cut in two pieces and one piece was placed in a cryotube. The colon was opened longitudinally, rinsed in $0.9 \%$ aqueous $\mathrm{NaCl}$ and cells were harvested by scraping the lumen with a Teflon scraper, and placed into a cryotube. After removing the capsule, the right testes were put in cryotubes and immediately frozen in isopropanol-containing freezing boxes for about $1 \mathrm{~h}$ and then transferred to $-80^{\circ} \mathrm{C}$ freezer until analyzed in the comet assay. The left testes were fixed in Bouin's fixative and routinely processed for paraffin fixation. One section $(3 \mu \mathrm{m})$ per testis from all of the animals in the control group, the low and the high dose group was stained with hematoxylin and eosin and evaluated by an experienced pathologist. A detailed qualitative examination of the testes was made, taking into account the tubular stages of the spermatogenic cycle. The examination was conducted to identify treatment-related effects such as missing germ cell layers or types, retained spermatids, multinucleate or apoptotic germ cells and sloughing of spermatogenic cells into the lumen.

\section{Alkaline version of the Comet assay}

In vivo

The comet assay was performed according to OECD (2014) and Tice et al. (2000), with minor modifications according to the manufacturer of the CometAssay®Kit (Trevigen, 
Gaithersburg, MD, USA). Liver, kidney, lung and urinary bladder from each mouse were homogenized in a Downs (VWR, Soeborg, Denmark) homogenizer containing ice-cold Hank's balanced salt solution $\left(\mathrm{Ca}^{2+}-\right.$ and $\mathrm{Mg}^{2+}$-free $)$ containing $0,02 \mathrm{~mol} / \mathrm{L}$ ethylenediaminetetracetate (EDTA) (VWR), and $10 \%$ dimethyl sulfoxide (DMSO) (SigmaAldrich). The colon scrapings were mixed with ice-cold mincing solution. Suspensions containing 2000-4000 cells, measured by means of a nucleocounter (type NC 3000, ChemoMetec, Alleroed, Denmark), were mixed with $150 \mu$ L molten CometAssay® LM agarose (Trevigen). Thirty $\mu \mathrm{L}$ of this mixture was applied onto one sample area of two duplicate slides (one gel per slide) consisting of twenty gels (CometSlide ${ }^{\mathrm{TM}} \mathrm{HT}$, Trevigen).

The cryotubes with the testes were each prepared as described in Hansen et al. (2014). Thirty $\mu \mathrm{L}$ of the different tissue mixtures was applied onto one sample area of two gels on two different slides (one gel on one slide) consisting of 20 gels (CometSlide ${ }^{\mathrm{TM}}$ HT, Trevigen). After solidification, the embedded cells were lysed in cold alkaline lysis buffer for $60 \mathrm{~min}$. For DNA unwinding, the slides were placed in alkaline electrophoresis solution $(\mathrm{pH}>13)$ in the electrophoresis jar at $4^{\circ} \mathrm{C}$ for $40 \mathrm{~min}$, and electrophoresis was run in the same buffer for 30 $\min$ at $4^{\circ} \mathrm{C}(1 \mathrm{~V} / \mathrm{cm})$. After neutralization, the samples were fixed in $96 \%$ ethanol. For DNA staining, $10 \mu \mathrm{L}$ SYBR Green solution (1 $\mu \mathrm{L}$ SYBR Green (VWR) in $10 \mathrm{~mL}$ TE buffer) was added to each gel together with a drop of antifade solution to avoid fading. Negative controls (Caco-2 cells in culture medium) and positive controls (Caco-2 cells exposed to $0.02 \%$ and $0.05 \%$ EMS for 30 min) were included with each 20 gels slide for each electrophoresis run with one sample of each concentration on two duplicate slides (one gel on one slide). Fully automatic comet assay scoring was performed using the PathfinderTMCellscan Comet imaging system (IMSTAR, Paris, France). The IMSTAR system, including validation in the low DNA damage range, is described in details in Sharma et al. (2012). At present our software algorithm is not able to distinguish between haplo- and diploid cell types, therefore 
we did not distinguish between different cell types. Briefly, tail intensity (\% tail DNA) of each comet was used. The number of cells scored on the gels depended on the cell density of the gels. Subsequently, 100 cells from each gel were randomly selected for further analysis in a way that assured that cells from the whole gel were covered. Hence, for each mouse 200 cells were analyzed (100 cells per gel and two gels per mouse). One hundred cells were selected for each gel for analysis because that was the minimum number on some gels. The comet distributions of the samples showed non-normal distributions, therefore median values for each tissue from each animal were used, and the mean of the median values were evaluated in statistical analysis. Up to 350 cells were scored on some gels and we also analyzed the data with all the cells scored on each gel. However, it did not make a difference in the statistical analysis compared to 100 cells on each gel.

\section{Comet assay in human sperm cells}

Human sperm samples were purchased from Nordic Cryobank (Copenhagen, Denmark) and stored at $-80^{\circ}$ C. Samples from this place were analysed according to WHO criteria (Esteves et al. 2012) including sperm volume, concentration, motility and morphology. After thawing, sperm samples from three men were pooled. From this mixture $5 \mu \mathrm{L}$ sperm was mixed with 1 mL phosphate-buffere saline ( $\mathrm{PBS}, \mathrm{pH}=7.4)($ ChemoMetec) and this was the final cell suspension. Based on cell viability data, BPA was tested in the following concentrations using DMSO (Sigma-Aldrich) as a solvent; 1, 1.5, 2 and $3 \mu \mathrm{mol} / \mathrm{L}$. BPA was weighed and added to DMSO (Sigma-Aldrich) and put in an ultrasonic bath (Branson 200, Bie \& Berntsen, Roedovre, Denmark) for five minutes. Then the BPA suspension was mixed with the final cell suspension in a total volume of $1000 \mu \mathrm{L}$ to give the mentioned concentrations. Control samples consisted of $5 \mu \mathrm{L}$ DMSO, $990 \mu \mathrm{L}$ PBS (ChemoMetec) and $5 \mu \mathrm{L}$ final cell suspensions. EMS was used as the positive control in a concentration of $600 \mu \mathrm{m} / \mathrm{L}$. The samples were incubated at $32{ }^{\circ} \mathrm{C}$ for one hour according to Baumgartner et al. (2012) and then 
centrifuged at $450 \mathrm{x} \mathrm{g}$ for ten minutes at room temperature. Hereafter the cell pellet was resuspended in $420 \mu \mathrm{L}$ PBS (ChemoMetec). To exclude the effect of DNA degradation associated with cytotoxicity resulting in false positive responses (Tice et al. 2000), the cell viability of the BPA samples was measured with a Nucleocounter NC 3000 (ChemoMetec) according to the manufacturers sheet (ChemoMetec 2014). Forty $\mu \mathrm{L}$ of reagent $\mathrm{S} 100$ (ChemoMetec) or PBS (ChemoMetec) was added to $100 \mu \mathrm{L}$ cell suspension. Reagent S100 is used for determination of the total concentration of sperm cells and PBS is used for determination of non-viable sperm cells. An SP1-Cassette ${ }^{\mathrm{TM}}$ (ChemoMetec) was used for the cell suspensions with S100 and PBS and the concentrations were measured with the Nucleocounter NC 3000 (ChemoMetec). Viable cells were calculated by subtracting the results with cells with PBS from the cells with reagent S100. Each concentration was scored in three independent experiments and two replicates of each experiment.

For sperm cells it is necessary to use a modified version of the alkaline comet assay to enable DNA migration from the compact sperm chromatin (Speit, Vasquez and Hartmann 2009). Three microliters of the samples were mixed with $150 \mu \mathrm{L}$ of the $1.5 \%$ molten CometAssay TM LMAgarose (Trevigen). Five microliters of this mixture was applied onto three gels on two different slides (three gels on one slide) consisting of 20 gels (CometSlide ${ }^{\mathrm{TM}} \mathrm{HT}$, Trevigen). After solidification the slides were lysed in a cold lysis buffer (sodium chloride 2.5 M, EDTA $0.1 \mathrm{~mol} / \mathrm{L}$ and Trizma ${ }^{\circledR}$ base $10 \mathrm{mmol} / \mathrm{L}, 0.8 \mathrm{~g}$ dithithreitol/L) cold alkaline lysis buffer for 60 minutes. Hereafter the slides were placed in another lysis buffer (sodium chloride $2.5 \mathrm{~mol} / \mathrm{L}$, EDTA $0.1 \mathrm{~mol} / \mathrm{L}$ and Trizma®base $10 \mathrm{mmol} / \mathrm{L}$, proteinase $\mathrm{k} 27 \mathrm{mg} / \mathrm{L}$ ) for 60 minutes. For DNA unwinding, the slides were placed in the alkaline electrophoresis solution $(\mathrm{pH}>13)$ in the electrophoresis jar at $4^{\circ} \mathrm{C}$ for 40 minutes, and electrophoresis was run in the same buffer for $30 \mathrm{~min}$ at $4^{\circ} \mathrm{C}(1 \mathrm{~V} / \mathrm{cm}$ and $270 \mathrm{~mA})$. After neutralization, fixation in $96 \%$ ethanol and DNA staining with $10 \mu \mathrm{L}$ SYBR Green solution $(1 \mu \mathrm{L}$ SYBR Green in 10 
mL TE buffer) on all gels of the slides and a drop of antifade solution was added to each gel to avoid fading. The slides were scored with the Pathfinder Cellscan Comet imaging system (IMSTAR). For each concentration six gels were scored (three gels per slide and two duplicate slides) and 100 cells randomly selected were scored per gel. For each concentration 600 cells were scored, and each concentration was scored in three independent experiments.

\section{Statistics}

The in vivo comet assay data were analyzed using a linear mixed-effects model with dose as a fixed effect and animal as a random effect. Dunnett's test was subsequently applied to compare the three dose groups to the corresponding control group. SAS Enterprise Guide 4.3 was used. The values given in Table 1 were calculated by first averaging the two median values obtained for each animal (i.e. one value for each gel and two gels per animal) and from these values the average and standard deviation were calculated. The positive control dose group was compared to the control dose group with an unpaired two-tailed t-test. Prior to statistical analysis the data were log transformed (natural logarithm) as recommended for in vivo comet assay data by Hansen et al. 2014 and Smith et al. 2008.

The human sperm cells comet assay data were analyzed by means of one-way ANOVA with Dunnett's test to compare the dosed groups with the control group. The positive control group (exposed to EMS) was analyzed against the control dose group by use of a two-tailed, unpaired t-test. GraphPad Prism 5.0 was used as statistical software. The values of \% tail DNA shown in Figure 2 were calculated (mean value and standard deviation) by first averaging the two duplicate gels from two slides and then averaging the values from three gels. The human sperm cells viability data were analysed by means of one-way ANOVA with Dunnett's test to compare the BPA concentrations with the control group. 


\section{Results}

\section{Comet assay in mouse tissues}

Table 1 shows the results of the six tissues examined for DNA damage by the in vivo comet assay in CD-1 mice. For all six tissues the positive control dose group, i.e. EMS treated mice, showed significantly higher levels of DNA strand breaks than the control dose group. None of the tissues showed an effect of BPA except the testes, in which an increased level of DNA strand breaks was observed at the lowest dose compared to the control dose group $(\mathrm{p}<0.001)$. However, no linear dose response relationship was observed as the effects at the medium and highest doses were at the same level as the control group. The mean value of the lowest dose group (8\% tail DNA) exceeded the $95 \%$ confidence interval distribution (3.1-4.5\% tail DNA, $\mathrm{n}=20$ mice in four different animal studies) of our laboratory's historical control distribution for CD-1 mice exposed to corn oil.

\section{Table 1.}

Histopathological investigation of the testicular samples did not show any clear treatment dose-related effects (Figure 1 and Table 2). In all dose groups, occasional sloughing of germ cells was seen (mild, one animal per dose group). In the low dose BPA group, one animal displayed mild degeneration of seminiferous epithelium with apoptosis of pachytene spermatocytes and missing germ cell layers in a few tubules. One control had aggregated germ cells in the lumen (multinucleated giant cell) of one tubule. These observations were mild and only seen in a few animals and are therefore not considered to reflect any treatment related effect.

\section{Figure 1. and Table 2.}




\section{Comet assay in human sperm cells}

Figure 2 shows the results of cell viability data of BPA in human sperm cells (A) and the comet assay (B). The concentration of $3 \mu \mathrm{mol} / \mathrm{L}$ reduced cell viability to $60 \%$ and was therefore the highest concentration used for the comet assay. Recommendations of the comet assay have been published, to avoid the testing of concentrations that decrease viability, compared to the concurrent control cultures, by more than about 30\% (Anderson, $\mathrm{Yu}$ and McGregor 1998; Tice et al. 2000). There were no statistically significant differences in \% tail DNA between the control samples and the four concentrations tested for DNA strand breaks (Fig. 2B). The positive control EMS was significantly different from control samples, demonstrating the sensitivity of the assay.

\section{Figure 2.}

\section{Discussion}

\section{Comet assay in animal testicular cells and sperm cells}

In the present study no DNA damage after oral gavage exposure to mice was observed in the in vivo comet assay in cells extracted from the liver, kidney, urinary bladder, colon and lungs. A significantly increased level of DNA strand breaks in testes was observed only in the lowest dose tested (125 mg/kg bw). Interestingly, the two other doses (250 and $500 \mathrm{mg} / \mathrm{kg}$ bw) were not different from the control dose group, indicating no linear dose response relationship. To our knowledge only one other study on BPA has investigated induction of DNA strand breaks in the comet assay in cells from the entire testicle (Dobrzynska and Radzikowska 2013). In that study, Pzh:SFIS male mice were exposed to BPA via drinking water for two weeks in doses from 5 to $40 \mathrm{mg} / \mathrm{kg}$ bw/day, and a dose dependent increase in DNA strand breaks was observed in testicular cells. To some extent, this supports the finding 
of increased DNA strand breaks in the current study, although dosing regimens differed. The effect was observed both at $24 \mathrm{~h}$ and 5 weeks after the end of the exposure. However, both sampling times are unusual in the in vivo comet assay according to the OECD guideline. The current finding is strengthened by the fact that the mean value of the lowest dose group is outside the 95 confidence interval distribution of our laboratory's historical control distribution for CD-1 mice exposed to corn oil. The observed increase from $3.3 \%$ tail DNA to $8 \%$ tail DNA is considered to be of biological relevance and to have potential for causing mutations. One of the strengths of the comet assay is to detect relatively small increases in DNA strand breaks (Tice et al. 2000). Positive findings in the comet assay may not be solely due to genotoxicity; target tissue toxicity may also result in increases in DNA migration and histopathological changes are considered a relevant measure of tissue toxicity (OECD 2014). In the current study, no toxic effects on testis histology were observed. Histology was not examined by Dobrzynska and Radzikowska 2013. To further elucidate the dose-response relationship of DNA strand breaks in mice testicular cells it would be necessary to test in a wider range of doses below $125 \mathrm{mg} / \mathrm{kg}$ bw/day and possibly with a longer exposure regime than 24 hours.

Mouse testes comprises different cell populations including somatic supportive Sertoli cells, differentiating germ cells in various stages of spermatogenesis and spermiogenesis, interstitial Leydig cells, macrophages, and fibroblasts as well as blood vessels and lymphatic vessels containing different cell populations. Therefore, the DNA isolated from the entire testicular tissue origins from a mixture of different cell types (Hansen et al. 2014; Svingen and Koopman 2013). An effect in testes is therefore not necessarily reflective of germ cell damage; however it indicates that the test substance reaches the testes. 
Two studies have investigated DNA strand breaks using the comet assay in rat germ cells. In the first study, rats were orally exposed to BPA for 6 days and a significant increase in DNA strand breaks was seen in epididymal sperm cells in the high dose group of $5 \mathrm{mg} / \mathrm{kg} \mathrm{bw} / \mathrm{day}$ (Tiwari and Vanage 2013) that is a much lower dose compared to the present study. However, this was associated with a marked reduction in sperm production and as histopathology was not performed it remains unknown if the positive effect was due to tissue toxicity. In another study by Wu et al. (2013), a significant increase in DNA strand breaks in isolated spermatocytes was observed compared to the control rats after ten days of oral gavage exposure (200 mg/kg bw/day) and 24 hours after the last dosing. Histopathology of the testes was performed and no changes were observed in the treated rats. Thus, there are some indications that BPA induces DNA strand breaks in rat sperm cells as well as in whole testis cells. However, it is currently not clear whether these effects are seen at certain dose intervals only, and the understanding of dose-response relationships remains limited.

\section{Histological effects of adult BPA exposure}

Overall, no treatment-related effects were observed in the histological examination of testes samples three hours after the last exposure following exposure on two consecutive days. However, due to the nature of spermatogenesis, it is possible that histological effects would only be detectable several days after dosing, when consequences of possible stage-specific effects may become visible as changes in subsequent stages (Creasy 1997). One study on adult exposure to BPA have described histological changes in testes after subcutaneously exposure (20 and $200 \mu \mathrm{g} / \mathrm{kg}$ bw/injection) to mice and rats for six days (Toyama et al. 2004). However, in a larger two-generation study, no histological changes were seen in parental (F0) testis following BPA exposure at doses from 0.003 to $600 \mathrm{mg} / \mathrm{kg}$ bw/day (Tyl et al. 2008). A recent study showed marked reduction of epididymal sperm reserves and daily sperm 
production in adult rats after 40 days of exposure to 5 or $25 \mathrm{mg} / \mathrm{kg}$ bw/day of BPA

(Wisniewski et al. 2015), and also the two-generation study indicated reduced epididymal sperm production at $600 \mathrm{mg} / \mathrm{kg}$ bw/day in parental males (F0) (Tyl et al. 2008). These and other findings suggest that BPA does affect testicular structure or function at some dose levels.

\section{Comet assay in other animal tissues}

Induction of DNA strand breaks were observed in spleen, kidney and lung cells in mice (Dobrzynska and Radzikowska 2013; Gajowik, Radzikowska and Dobrzynska 2013). These results are conflicting with the present study in which no effects were observed in kidney and lung cells after two days of BPA exposure to $125-500 \mathrm{mg} / \mathrm{kg}$ bw/day. The longer exposure periods in those studies (6-14 days) may be of importance and since histopathology was not performed, it remains unknown whether the observed effects are due to tissue toxicity. In two studies, induction of DNA strand breaks in blood lymphocytes have been reported in rats (Ulutas et al. 2011; Tiwari et al. 2012) and one study in mice (Dobrzynska and Radzikowska 2013). Some of these studies show limitations such as insufficient number of doses applied and absence of histopathological investigation at positive findings. Therefore, better designed studies are needed to elucidate the potential of BPA to induce DNA strand breaks in vivo in somatic cells.

\section{Other genotoxicity tests}

Other in vivo genotoxicity end-points have been investigated after BPA exposure. BPA caused DNA adducts in liver and mammary tissues in female mice at $200 \mathrm{mg} / \mathrm{kg}$ bw/day (Izzotti et al. 2009), and in the liver of male rats at $200 \mathrm{mg} / \mathrm{kg}$ bw/day (Atkinson and Roy 
1995), however in both studies only one dose was applied and more detailed investigations are needed to make conclusions.

Most of the published studies did not report induction of chromosomal damage (De Flora et al. 2011; Masuda et al. 2005; Naik and Vijaylakshmi 2009; Pacchierotti et al. 2008) except for the studies by Tiwari et al. 2012 and Gajowik, Radzikowska and Dobrzynska 2013, indicating that BPA did not induce chromosomal damage.

One possible mechanism suggested to lead to the potential genotoxic effects of BPA is oxidative stress. BPA could induce oxidative damage by disturbing the balance between reactive oxygen species ROS and the antioxidant defense system. A recent review of induction of oxidative stress by BPA reveals that there is growing and compelling evidence that different doses promote the generation of ROS, alter the antioxidant balance, induce mitochondrial dysfunction, and promote changes in a number of cell signaling pathways related to oxidative stress (Gassman 2017).

Conflicting results are seen regarding effects of BPA on other genotoxicity end-points than DNA strand breaks and more detailed investigations with standardized test conditions are needed to make firm conclusions. Furthermore, it would be relevant to investigate the role of ROS in genotoxicity studies of BPA.

\section{Comet assay in human sperm cells}

Studies of DNA damage in human sperm cells after BPA exposure have been lacking. In one study, the biomarker of oxidative DNA damage, $8 \mathrm{OHdG}$, was produced and measured by flow cytrometric detection of $8 \mathrm{OHdG}$ in sperm cells at the only tested concentration of 300 $\mu \mathrm{mol} / \mathrm{L}$ (Barbonetti et al. 2016). A poorly reported study showed no effect in in vitro comet assay on human sperm cells (Bennetts et al. 2008). In the present study, no effect of DNA 
strand breaks was observed after BPA exposure to human sperm cells, indicating that BPA did not exert DNA damage in these cells up to slightly cytotoxic concentrations. In all cases testing was done without metabolizing enzymes and it could be interesting to investigate if BPA metabolites would induce DNA strand breaks in human sperm cells.

\section{Conclusion}

In the present study, BPA exposure by oral gavage to male CD-1 mice induced DNA strand breaks in testicular cells only in the lowest dose, no effect was observed in the medium or the highest dose tested. Histopathological investigation of the testicular samples did not show any treatment dose-related effects. No induction of DNA strand breaks were observed in liver, kidney, colon, urinary bladder and lung cells of male CD-1 mice. These data emphasize the need for further studies on DNA strand breaks in vivo in mice after oral exposure and at doses below $125 \mathrm{mg} / \mathrm{kg}$ bw/day. BPA did not induce DNA strand breaks in human sperm cells in vitro, but further testing of BPA metabolites is warranted,

\section{Funding information}

This work was partly funded by the Danish EPA.

\section{Acknowledgements}

The authors would like to acknowledge Vivian Jørgensen and Anne-Marie Vinggaard from the Technical University of Denmark, National Food Institute, Division of Diet, Diseases Prevention and Toxicology. Furthermore the Animal facility personnel at the Technical 
University of Denmark, National Food Institute are also gratefully acknowledged. Finally we would like to acknowledge Charles Homsy and Francoise Soussaline, IMSTAR S.A. France.

\section{References}

Anderson., D., T-W. Yu, and D.B. McGregor. 1998. "Comet Assay Responses as Indicators of Carcinogen Exposure”. Mutagenesis 13 (6): 539-555.

Atkinson, A., and D. Roy. 1995. "In-Vivo DNA Adduct Formation by Bisphenol-A.” Environmental and Molecular Mutagenesis 26 (1): 60-66.

Barbonetti, A., C. Castellini, N. di Giammarco, G. Santilli, S. Francavilla, and F. Francavilla. 2016. "In Vitro Exposure of Human Spermatozoa to Bisphenol A Induces Pro-Oxidative/Apoptotic Mitochondrial Dysfunction." Reproductive Toxicology 66: 61-67.

Baumgartner, A., M. Kurzawa-Zegoti, J. Laubenthal, E. Cemeli, and D. Anderson. 2012. "Comet-Assay Parameters as Rapid Biomarkers of Exposure to Dietary/Environmental Compounds - An in vitro Feasibility Study on Spermatozoa and Lymphocytes." Mutation Research/Genetic Toxicology and Environmental Mutagenesis 743 (1-2) 25-35.

Bennetts, L.E., G.N. de Iuliis, B. Nixon, M. Kime, K. Zelski, C.M. McVicar, S.E. Lewis, and R.J. Aitken. 2008. "Impact of Estrogenic Compounds on DNA Integrity in Human Spermatozoa: Evidence for CrossLinking and Redox Cycling Activities." Mutation Research/Fundamental and Molecular Mechanisms of Mutagenesis 641 (1-2): 1-11.

ChemoMetec. 2014. "The NucleoCounter ${ }^{\circledR}$ SP-100 ${ }^{\mathrm{TM}}$ - For Total Count of Sperm Cells and Viability." ChemoMetec, Application note No. 999-0100 VER 01.2014.

Christiansen, S., M. Axelstad, J. Boberg, A.M. Vinggaard, G.A. Pedersen, and U. Hass. 2014. "Low-Dose Effects of Bisphenol A on Early Sexual Development in Male and Female Rats." Reproduction 147 (4): 477-487.

Creasy, D.M. 1997. "Evaluation of Testicular Toxicity in Safety Evaluation Studies: The Appropriate Use of Spermatogenic Staging.” Toxicologic Pathology 25 (2): 119-131.

De Flora, S., R. Micale, S. la Maestra, A. Izzotti, F. D’Agostini, A. Camoirano, S.A. Davoli et al. 2011. "Upregulation of Clusterin in Prostate and DNA Damage in Spermatozoa from Bisphenol A-Treated Rats and Formation of DNA Adducts in Cultured Human Prostatic Cells." Toxicological Sciences 122 (1): 45 51.

Dobrzynska, M.M., and J. Radzikowska. 2013. "Genotoxicity and Reproductive Toxicity of Bisphenol A and Xray/Bisphenol A Combination in Male Mice." Drug and Chemical Toxicology 36 (1): 19-26.

EFSA (European Food Safety Authority) 2015. Panel on Food Contact Materials. "Scientific Opinion on the Risks to Public Health Related to the Presence of Bisphenol A (BPA) in Foodstuffs: PART II Toxicological Assessment and Risk Characterisation.” EFSA Journal 13 (1): 1-621.

Ema, M., S. Fujii, M. Furukawa, M. Kiguchi, T. Ikka, and A. Harazano. 2001. "Rat Two-Generation Reproductive Toxicity Study of Bisphenol A.” Reproductive Toxicology 15 (5): 505-523.

Esteves, S.C., A. Zini, N. Aziz, J.G. Alvarez, E.S. Sabanegh Jr, and A. Agarwal. 2012. "Critical Appraisal of World Health Organization's New Reference Values for Human Semen Characteristics and Effect on Diagnosis and Treatment of Subfertile Men." Urology 79 (1): 16-22.

Gajowik, A., J. Radzikowska, and M.M. Dobrzynska. 2013. "Genotoxic Effects of Bisphenol A on Somatic Cells of Female Mice, Alone and in Combination with X-rays.” Mutation Research-Genetic Toxicology and Environmental Mutagenesis 757 (2): 120-124.

Gassmann, N.R., 2017. "Induction of Oxidative Stress by Bisphenol A and its Pleiotropic Effects." Environmental \& Molecular Mutagenesis 58 (2): 60-71.

Hansen, M.K., A.K. Sharma, M. Dybdahl, J. Boberg, and M. Kulachi. 2014. "In Vivo Comet Assay - Statistical Analysis and Power Calculations of Mice Testicular Cells.” Mutation Research-Genetic Toxicology and Environmental Mutagenesis 774: 29-40.

Hunt, P.A., K.E. Koehler, M. Susiarjo, C.A. Hodges, A. Ilagan, R.C. Voigt, S. Thomas, B.F. Thomas, T.J. Hassold. 2003. "Bisphenol A Exposure Causes Meiotic Aneuploidy in the Female Mouse." Current Biology 13 (7): 546-553.

Izzotti, A., S. Kanitz, F. d'Agostini, A. Camoirano, and S. de Flora. 2009. "Formation of Adducts by Bisphenol A, an Endocrine Disruptor, in DNA in Vitro and in Liver and Mammary Tissue of Mice." Mutation Research/Genetic Toxicology and Environmental Mutagenesis 679 (1-2): 28-32. 
Johnson, G.E., and E.M. Parry. 2008. "Mechanistic Investigations of Low Dose Exposures to the Genotoxic Compounds Bisphenol-A and Rotenone." Mutation Research/Genetic Toxicology and Environmental Mutagenesis 651: 56-63.

Kanno, J., L. Onyon, J. Haseman, P. Fenner-Crisp, J. Ashby, W. Owens, and Organisation for Economic Cooperation and Development. 2001. "The OECD Program to Validate the Rat Uterotrophic Bioassay to Screen Compounds for In Vivo Estrogenic Responses: Phase 1.” Environmental Health Perspectives 109 (8): 785-794.

Masuda, S., Y. Terashima, A. Sano, R. Kurota, Y. Sugiyama, K. Shimoi, K. Tanji, H. Yoshioka, Y. Terao, and N. Kinae. 2005. "Changes in the Mutagenic and Estrogenic Activities of Bisphenol A upon Treatment with Nitrite." Mutation Research/Genetic Toxicology and Environmental Mutagenesis 585: 137-146.

Naik, P., and K.K. Vijayalaxmi. 2009. "Cytogenetic Evaluation for Genotoxicity of Bisphenol-A in Bone Marrow Cells of Swiss Albino Mice." Mutation Research/Genetic Toxicology and Environmental Mutagenesis 676 (1-2): 106-112.

OECD. OECD Test Guideline No. 489. 2014. "In Vivo Mammalian Alkaline Comet Assay.” OECD. TG 489: 125.

Pacchierotti, F., R. Ranaldi, U. Eichenlaub-Ritter, S. Attia, and I.D. Adler. 2008. "Evaluation of Aneugenic Effects of Bisphenol A in Somatic and Germ Cells of the Mouse." Mutation Research/Genetic Toxicology and Environmental Mutagenesis 651 (1-2): 64-70.

Sharma, A.K., F. Soussaline, J. Sallette, and M. Dybdahl. 2012. "The Influence of the Number of Cells Scored on the Sensitivity in the Comet Assay." Mutation Research/Genetic Toxicology and Environmental Mutagenesis 749 (1-2): 70-75.

Smith, C.C., D.J. Adkins, E.A. Martin, and M.R. O’Donovan. 2008. "Recommendations for Design of the Rat Comet Assay." Mutagenesis 23 (3): 233-240.

Speit, G., M. Vasquez, and A. Hartmann. 2009. "The Comet Assay as an Indicator Test for Germ Cell Genotoxicity." Mutation Research-Reviews in Mutation Research 681 (1): 3-12.

Svingen, T., and P. Koopman. 2013. "Building the Mammalian Testis: Origins, Differentiation, and Assembly of the Component Cell Populations." Genes \& Development 27 (22): 2409-2426.

Tice, R.R., E. Agurell, D. Anderson, B. Burlinson, A. Hartmann, H. Kobayashi, Y. Miyamae et al., 2000. "Single Cell Gel/Comet Assay: Guidelines for In Vitro and In Vivo Genetic Toxicology Testing." Environmental \& Molecular Mutagenesis 35 (3): 206-221.

Tiwari, D., J. Kamble, S. Chilgunde, P. Patil, G. Maru, D. Kawle, U. Bhartiya, L. Joseph, and G. Vanage. 2012. "Clastogenic and Mutagenic Effects of Bisphenol A: An Endocrine Disruptor." Mutation Research/Genetic Toxicology and Environmental Mutagenesis 743 (1-2): 83-90.

Tiwari, D., and G. Vanage. 2013. "Mutagenic Effect of Bisphenol A on Adult Rat Male Germ Cells and their Fertility." Reproductive Toxicology 40: 60-68.

Toyama, Y., F. Suzuki-Toyota, M. Maekawa, and K. Toshimori. 2004. "Adverse Effects of Bisphenol A to Spermiogenesis in Mice and Rats.” Archives of Histology and Cytology 67 (4): 373-381.

Tyl, R.W., C.B. Myers, M.C. Marr, C.S. Sloan, N.P. Castillo, M.M. Veselica, J.C. Seely et al. 2008. "TwoGeneration Reproductive Toxicity Study of Dietary Bisphenol A in CD-1 (Swiss) Mice.” Toxicological Sciences 104 (2): 362-384.

Ulutas, O., N. Yildiz, E. Durmaz, M.A. Ahbab, N. Barias, and I. Cok. 2011. "An in Vivo Assessment of the Genotoxic Potential of Bisphenol A and 4-Tert-Octylphenol in Rats.” Archives of Toxicology 85 (8): 995 1001.

Wisniewski, P., R.M. Romano, M.M. Kizys, K.C. Oliveira, T. Kasamatsu, G. Giannocco, M.I. Chiamolera et al. 2015. "Adult Exposure to Bisphenol A (BPA) in Wistar Rats Reduces Sperm Quality with Disruption of the Hypothalamic-Pituitary-Testicular Axis.” Toxicology 329: 1-9.

Wu, H.J., C. Liu, W.X. Duan, S.C. Xu, M.D. He, C.H. Chen, Y. Wang et al. 2013. "Melatonin Ameliorates Bisphenol A-Induced DNA Damage in the Germ Cells of Adult Male Rats." Mutation Research/Genetic Toxicology and Environmental Mutagenesis 752 (1-2): 57-67. 


\section{Figure legends}

Figure 1. Mouse testis, original magnification 20x. A: control group, B: Biphenol A $125 \mathrm{mg} / \mathrm{kg} \mathrm{bw} /$ day, C: Bisphenol A $500 \mathrm{mg} / \mathrm{kg}$ bw/day. No differences between exposure groups were observed.

Figure 2. Cell viability data (Figure $A$ ) and DNA damage data (Figure B) of bisphenol A (BPA) in human sperm cells, $n=3$ (Fig. B: For each experiment, 600 cells were scored for each concentration). Data were analyzed by means of a one-way ANOVA with Dunnett's test to compare the exposed cell concentrations with the controls. The positive control (exposed to ethylmethane sulfonate (EMS) at $600 \mu \mathrm{mol} / \mathrm{L}$ ) was analyzed against the negative control by use of a two-tailed unpaired t-test. $*=p<0.05,{ }^{* *}=p<0.01$. 

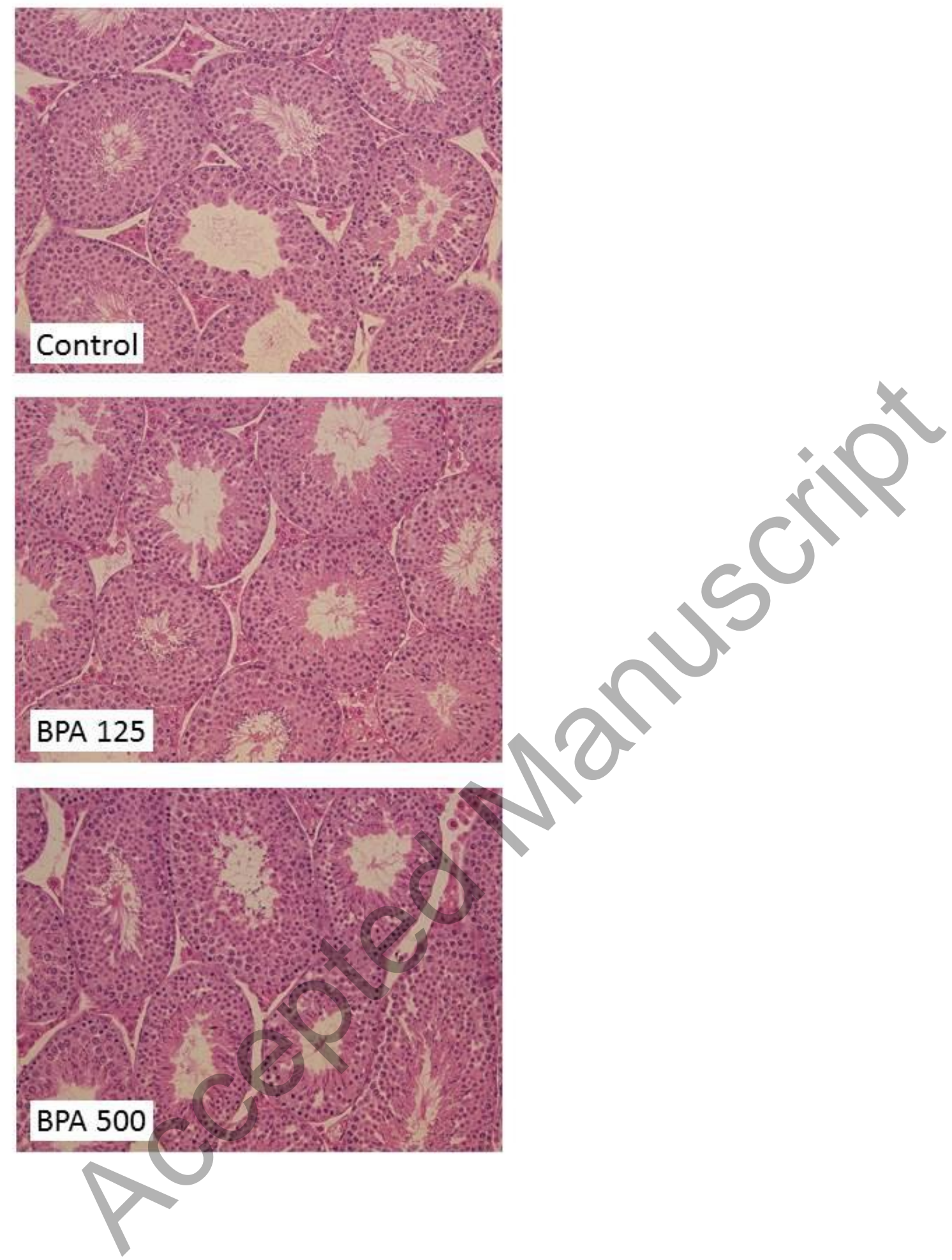


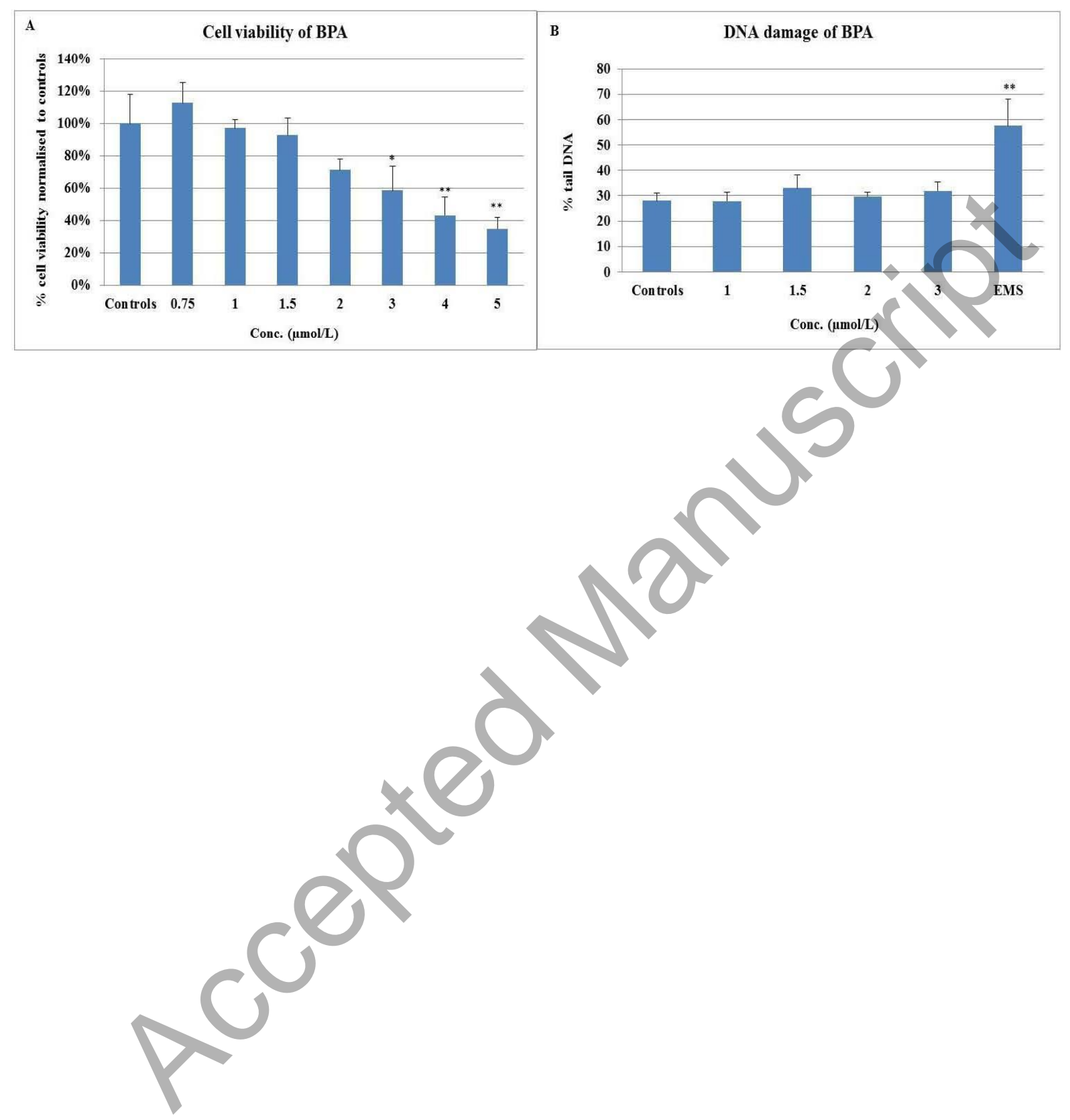


Table 1. Results of DNA strand breaks (\% tail DNA) in CD-1 male mice after oral gavage of bisphenol A or corn oil as negative control. There were five animals per group and 200 cells were scored for each mouse. Data were analyzed by means of linear mixed-effects model with dose as a fixed effect and animal as a random effect. Dunnett's test was subsequently applied to compare the three dose groups to the control group. ${ }^{*} \mathrm{p}<0.05, * * \mathrm{p}<$ $0.01, * * * p<0.001$. The positive control group dosed with ethylmethane sulfonate (EMS) was compared with the control (two-tailed, unpaired t-test). Internal standards: positive control (Caco- 2 cells exposed to $0.02 \%$ and $0.05 \%$ EMS): $n=10, \%$ tail DNA, mean \pm s.d., $0.2 \%$ EMS: $19.9 \pm 5.7 ; 0.5 \%$ EMS: $36.6 \pm 8.5$; negative controls (untreated Caco-2 cells): $2.8 \pm 1.4$

\begin{tabular}{lccccc}
\hline & & \multicolumn{3}{c}{ Doses (mg/kg/b.w./day) } & Positive control, EMS (mg/kg/bw/day) \\
& Control & 125 & 250 & 500 & 300 \\
\hline Liver & $2.2 \pm 0.9$ & $4.3 \pm 3.0$ & $1.8 \pm 1.2$ & $6.2 \pm 5.0$ & $16.1 \pm 8.2^{* * *}$ \\
\hline Kidney & $3.5 \pm 2.4$ & $5.6 \pm 4.4$ & $2.1 \pm 1.2$ & $2.0 \pm 0.6$ & $9.4 \pm 2.3^{* *}$ \\
& & & & & $10.9 \pm 1.4^{* * *}$ \\
\hline Testis & $3.3 \pm 0.6$ & $8.0 \pm 2.9 * * *$ & $2.6 \pm 0.4$ & $2.1 \pm 0.3$ & $18.4 \pm 4.4^{*}$ \\
\hline Urinary bladder & $9.6 \pm 6.0$ & $25.6 \pm 20.9$ & $11.1 \pm 7.9$ & $13.7 \pm 5.5$ & $66.4 \pm 6.9 *$ \\
\hline Colon & $40.4 \pm 17.3$ & $23.6 \pm 20.2$ & $32.0 \pm 15.9$ & $57.3 \pm 18.8$ & $7.7 \pm 2.0^{* * *}$ \\
\hline Lung & & & & \\
\hline
\end{tabular}

Table 2. Results of histological examination of testes of mice dosed by gavage to bisphenol A.

Numbers of affected mice are listed below.

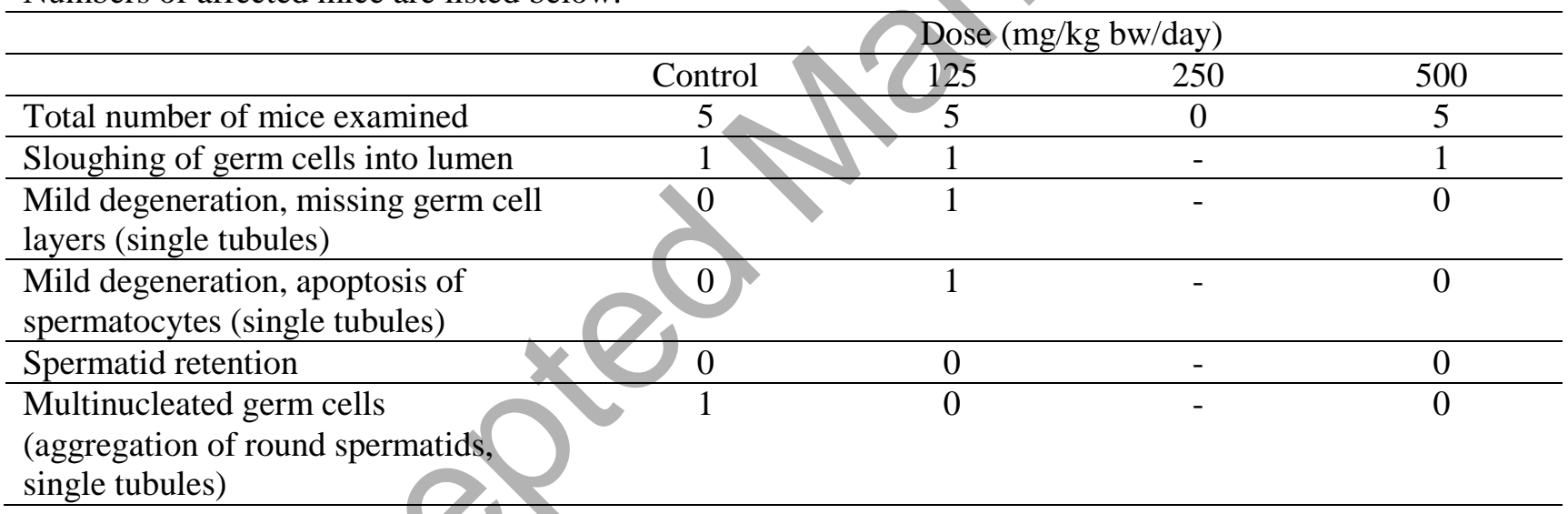

